\title{
Servant Leadership and Performance Employee: The Mediating Effect of Organizational Commitment
}

\author{
Marisi Pakpahan ${ }^{1, *}$, Hardianawati $^{1}$, Suwarlan $^{1}$ \\ ${ }^{1}$ Institut Bisnis dan Multimedia asmi, Jakarta, Indonesia \\ ${ }^{*}$ Corresponding author. Email: marisi.pakpahan@gmail.com
}

\begin{abstract}
Purpose - The leadership process is one of the important factors in directing employees to have good performance. This study focuses on the discussion of the antecedents of servant leadership variables with their influence on employee performance with organizational commitment in the workplace as a mediator. Design/methodology/approach - This research is a survey research conducted on alumni of the secretarial study program at IBM ASMI. The unit of analysis is an individual. The population consists of 170 alumni who graduated from 2019 to the past 5 years. The sample used was 123 respondents, namely $72 \%$ of the total population. The questionnaire was designed using a 5 Likert scale. Data is collected online using google form in the form of a link and sharing it through social media, namely, facebook for study programs, istagram, and whatsapp alumni groups. The results of the study were explained by descriptive and verification. Verification analysis was carried out using the Structural Equation Modeling (SEM) approach with the help of the Lisrel 8.8 statistical tool Findings - The results showed that there was no significant influence between servant leadership and organizational commitment, but there were positive results and had a significant impact on employee performance. Organizational commitment has a positive and significant effect on employee performance and when servant leadership is mediated by organizational commitment the results show a positive and significant effect on employee performance. Originality/value - The results of this study add to the limitations of the literature and provide empirical evidence of relationship between serving leadership, organizational commitment and employee performance. the results of previous studies that have been reviewed by researchers prove that serving leadership has a significance to organizational commitment, but in this study it is not in line with these studies. This research provides a different contribution from the previous one.
\end{abstract}

Keywords: Servant leadership, organizational commitment, employee performance

\section{INTRODUCTION}

Vocational education is an educational institution that emphasizes the practical skills needed to directly enter the world of work. Graduates of the secretarial study program whose names are now adjusted to the nomenclature set by the government to become office administration in accordance with Kepmenristekdikti No. 57 of 2019 concerning the name of study programs in tertiary institutions is expected to be absorbed directly in the business and industrial world. Vocational graduates of the office administration (secretarial) study program ASMI Multiedia and Business Institute (IBM ASMI) have been equipped with skills that are ready to work according to company needs.

According to the results of tracer studies conducted, the average secretarial study program alumni are absorbed in various business worlds with a waiting period of approximately three months. Graduates are assisted by work placement units to channel them to various companies. With a curriculum designed, graduates are expected to quickly adapt to the corporate environment through an internship program for each student. Thus, the company does not need to have a lot of time to provide supplies for them. It is hoped that with the skills they have, they will be able to work well as a leadership secretary and administrative staff, so that the leadership is helped by the work of secretaries / employees and can increase their commitment to the company.

Numerous studies have been conducted to investigate the different features of servant leadership that are employed specifically in education. The results show that there is a positive influence from the principal through leadership serving in higher education and there is teacher confidence in leadership [1].

Servant leadership is defined by the qualities of being a good listener, having self-awareness, empathy and management, which enables leaders to understand the 
needs of employees and optimize their potential, while at the same time adapting employee aspirations to organizational needs and goals. Servicing leaders place employees at the center of their attention and strive to attend to their needs while doing their best to foster employee development with adequate support and resources [2]. Socially, good work performance can increase empowerment and welfare for those around them [3]. Servant Leadership Model at JW Marriott Surabaya, namely voluntary subordination, transforming influence, responsible morality, authentic self, transcendent spirituality, covenant relationship, service administrator, empathy, awareness, listening, listening, community building, healing, commitment to people's growth, persuasion, conceptualization, and foresight [4]. Employee organizational commitment will shape the best performance of Pelabuhan Indonesia III employees. Good work performance is required by middle level employees at Pelabuhan Indonesia III, who are required for regulation, policy and information of all jobs from top managers to junior managers [5].

\section{LITERATURE REVIEW}

\subsection{Servant Leadership}

Servant leadership begin with a natural feeling that someone wants to serve first, then the choice leads someone to aspire to lead. Whether the first is to be a leader first or to serve first, this shows two extreme types that are part of the diversity of human nature [6]. Servant leadership is a leadership style that focuses on employees rather than organizational results whose main purpose is to serve followers [7]. Many benefits of servant leadership, practitioners must be prepared to put forth extraordinary efforts in developing a culture of servant leadership, starting with themselves as role models [8].

Building servant leadership requires a combination of conscientious and socially motivated people combined with servant leadership training [8]. It is necessary to confirm the relationship between the attributive values of serving leadership to employee commitment, where the results of serving leadership have a direct impact on commitment [9]. In order for leaders who serve to focus on employee development, they should meet the three basic psychological needs of employees, namely, autonomy, competence and relationship. It also shows how satisfaction of each need has unique predictive power because the three forms of need satisfaction are combined in different ways to elicit attitudes and behaviour that predict individual employee task performance [10].

\subsection{Organizational Commitment}

Organizational commitment is a component of behavior. Organizational commitment is a condition in which an employee sides with an organization and its values and goals, and intends to maintain its membership. A high level of organizational commitment means siding with the organization that recruits the employee [11].

Organizational commitment is a strong desire to remain a member of a particular organization, the desire to strive in accordance with the wishes of the organization and certain beliefs about acceptance of the goals and values of the organization. It can be interpreted that organizational commitment is a person's attitude that shows loyalty to an organization and the process by which a person expresses his concern for the organization [12].

\subsection{Employee Performance}

Employee performance can be defined as job performance which is the ratio between significant work and employee standards. Employee Performance is what employees do or don't do. From these two concepts it can be synthesized that Employee performance is the ability of employees multiplied by effort and support.

Bernardin and Russel stated for measuring the performance or work results of an employee, a list of questions is used which contains several dimensions of work results or performance. Performance needs to be measured by the leadership so that it can be known to what extent the performance development of an employee in particular and the organization in general. Bernandin and Russell define performance as

"... the record of outcomes produced on a specified job fuction or activity during a specified time period", (records of outcomes resulting from the function of a particular job or activity over a period of time) certain.

Mathis \& Jackson defines that employee performance is what affects how much workers contribute to the company which includes the quantity of output, quality of output, attendance at work and cooperative attitudes. Of course, the performance shown by an employee is influenced by various factors, including work motivation and work environment.

The relationship between each variable represented in Figure 1. The model shows three research constructs, namely servant leadership as a predictor, organizational commitment as mediation and secretary performance as a result. There are four hypotheses observed which are shown in the conceptual model as well as the hypothesis developed.

\section{METHOD AND MEASUREMENT}

This research uses a quantitative approach through a survey conducted on alumni of the ASMI Business and 
Multimedia Institute (IBM ASMI) secretarial study program with a graduation year of 5 years back since 2019. This type of research is correlational research. Correlational research is a type of nonexperimental research in which the researcher measures two variables and assesses the relationship between the variables with little or no effort to control for extraneous variables.

The population is 170 alumni who have graduated in the past 5 years since graduating in 2019. The variables in this study are classified into exogenous and endogenous variables. Serving leadership variable (X) is an exogenous variable, employee performance $(Z)$ is an endogenous variable. Organizational commitment $(\mathrm{Y})$ is an endogenous variable intervention. Servant leadership measurement uses a scale from Barbuto \& Wheeler with five dimensions, namely, Altruistic Calling, Emotional Healing, Wisdom, Persuasive Mapping, Organizational Stewardship. To measure organizational commitment using a questionnaire Mowday, Steers, Porter with 15 statement items. This questionnaire was also used by [5]. To measure employee performance using Bernandin and Russell with indicators of Quality, Quantity, Timeliness, Cost effectiveness, Need for supervision, Interpersonal impact. These three variables are measured by a value on a 5-point Likert scale ranging from 1 (strongly disagree) 2 (disagree) 3 (neutral) 4 (agree) 5 (strongly agree).

Data was collected through a questionnaire using google form, links were sent directly to respondents via the study program Facebook, Instagram, and the alumni group WhatsApp. Data were analyzed using the Structural Equation Modeling (SEM) approach with the help of Lisrel 8.8 statistical software. The research results were explained descriptively and verificatively.

\subsection{Conceptual Framework}

Further, according to the strong relationship from theoretical and empiric study from the variables that become the focus of this study, so that conceptual framework in this study has showed in Fig. 1.

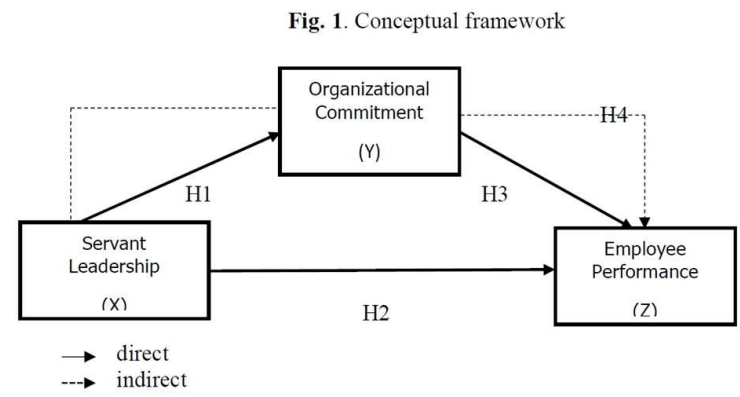

Figure 1. Conceptual Framework

\section{FORMULATION HYPOTHESIS}

It is necessary to confirm the relationship between the attributive values of serving leadership to employee commitment, where the results of serving leadership have a direct impact on commitment [9]. A potential contribution lies in that this study confirms the mediating role of leader commitment and organizational commitment on the relationship between servant leadership and participatory behavior in the context of the Korean Catholic church. Based on structural equation modeling, a linear relationship was found from servant leadership to leader commitment, to organizational commitment, and finally to member participatory behavior [13].

\section{H1: There is a servant leadership influence on organizational commitment}

When leaders care about employees, it will give them the opportunity to develop themselves, get information, and ultimately trust them so that employees will complete their tasks on time [14]. The concept of servant leadership comes primarily from the experience of Robert K. Greenleaf in the management of the teachings of Jesus. The resulting servant leadership model is characterized by a service orientation, a holistic outlook, and a moral spiritual emphasis, thereby expanding current models of servant leadership and existing work on contemporary leadership approaches [15].

The results showed that servant leadership has a direct influence on POS and performance, but only indirectly related to turnover intention and turnover through POS and performance [16]. Servicing leadership of sales managers is directly and positively related to the performance of members of the sales staff organization [17].

\section{H2: There is a servant leadership influence on employee performance}

Organizational commitment has a significant impact on employee performance in the workplace. Commitment can increase or hinder an employee's willingness to do the job, because it affects their productivity and quality of work. However, the relationship between the two is more complicated than the direct one: it is affected by job satisfaction. Therefore, organizations need to increase employee commitment to increase their job satisfaction and performance [18].

Organizational commitment affects job performance. This shows that if organizational commitment includes a strong belief and acceptance of the organization's values and goals for the better, then the employee's job is characterized by skills, effort and the nature of working conditions that will be better [19]. 
H3: There is an influence of organizational commitment on employee performance

Servant leadership, and organizational commitment have a constructive effect on the job performance of employees of Small and Medium Enterprises (SMEs) in Zimbabwe, there is a positive and significant relationship [20].

H4: There is a servant leadership influence on employee performance through organizational commitment

\section{FINDINGS}

\subsection{Description of Respondent}

Table 1. Explains demographic statistics for 123 respondents. Respondents who participated in this study were alumni of the Secretariat study program of the ASMI Business and Multimedia Institute (IBM ASMI) domiciled in DKI Jakarta. All respondents are female, with the latest diploma three education. Data were collected for 3 days, from 14-16 July 2020. The majority of respondents aged $21-25$ years were $58.1 \%$ of the total respondents, with a predominantly working period of under 5 years at $86 \%$. Meanwhile, the majority of the respondents' types of institutions/organizations work in private companies, $93.50 \%$ of the remaining work as civil servants (PNS) and employees of state-owned enterprises (BUMN). The majority of institutions / companies domicile $93.49 \%$ are located in DKI Jakarta, the rest are domiciled in West Java, Banten, and other places.

Table 1. Characteristic of Respondents

\begin{tabular}{|c|c|c|c|c|c|c|c|}
\hline $\mathrm{N}=123$ & & Total & $\%$ & $\mathrm{~N}=123$ & & Total & $\%$ \\
\hline \multirow[t]{3}{*}{ 1. Gender } & Male & 0 & 0 & 4. Work Period & $<5$ tahun & 106 & 86,2 \\
\hline & Female & 123 & 100 & & $5-10$ tahun & 17 & 13,8 \\
\hline & & 123 & 100 & & & 123 & 100 \\
\hline \multirow[t]{3}{*}{ 2. Age } & $21-25$ year & 72 & 58,5 & 5.Type of & Gov. Org & 8 & 6,50 \\
\hline & $26-30$ year & 51 & 41,5 & Institution & Privat Org. & 115 & 93,50 \\
\hline & & 123 & 0 & & & 123 & 100 \\
\hline \multirow[t]{5}{*}{ 3. Education } & D3 & 123 & 100 & 6. Domicile of & DKI & 115 & 93,49 \\
\hline & & & & Institution & Jabar & 4 & 3,25 \\
\hline & & 123 & 100 & & Banten & 3 & 2,43 \\
\hline & & & & & Other & 1 & 0,81 \\
\hline & & & & & & 123 & 100 \\
\hline
\end{tabular}

Source: data processed

\subsection{Descriptive statistics}

Descriptive assessment of each variable in this study, using an average score categorized into 5 interval scales. Data Table 2 shows the value of each variable as follows: (1) Descriptive statistical results for the average score of employee servant leadership variables (X) is high (3.19 from a scale of 5) with a standard deviation score of 0.47 . (2) The variable organizational commitment (Y) shows that the average score is also high (3.72 from a scale of 5 ), with a standard deviation score of 0.57. (3) Meanwhile the results of the employee performance variable $(Z)$ show that the average score is high ( 4.00 out of a scale of 5) with a standard deviation score of 0.30 .
Although the three variables are in the high category, the employee performance variable is the variable with the lowest score among other variables. This means that there are still many employees who are less committed to the company. Nearly $70 \%$ of employees feel that they are not working for the company they expected. This can be seen from the very high number of alumni who are absorbed in private companies. $t$ could be that the company is categorized as a middle to lower scale company, so there is a sense of not being proud of being an employee at the company. Unfortunately, the researchers did not examine more in the category of company scale where the alumni worked. 
Table 2. Descriptive statistics and category scoring based on a scale

\begin{tabular}{|c|c|c|c|c|c|c|c|}
\hline \multirow[t]{3}{*}{ Variable } & \multirow{3}{*}{$\begin{array}{l}\text { Skor } \\
\text { rata- } \\
\text { rat }\end{array}$} & \multirow{3}{*}{$\begin{array}{l}\text { Standar } \\
\text { deviasi }\end{array}$} & \multicolumn{5}{|c|}{ Skor interval } \\
\hline & & & $1.00-$ & 1,76 & 2,52 & 3,28 & 4.16 \\
\hline & & & 1,75 & 2,51 & 3,27 & 4,15 & 5.00 \\
\hline \multirow{6}{*}{$\begin{array}{l}\text { Servant Leadership } \\
\text { Organizational } \\
\text { Commitment } \\
\text { Employee } \\
\text { Performance }\end{array}$} & 3,51 & 0,47 & \multirow{6}{*}{$\begin{array}{l}\text { very } \\
\text { low } \\
\text { very } \\
\text { low } \\
\text { very } \\
\text { low }\end{array}$} & \multirow[t]{2}{*}{ low } & \multirow[t]{2}{*}{ medium } & \multirow[t]{2}{*}{ high } & very \\
\hline & & & & & & & high \\
\hline & 3,72 & 0,57 & & \multirow[t]{2}{*}{ low } & \multirow[t]{2}{*}{ medium } & \multirow[t]{2}{*}{ high } & very \\
\hline & & & & & & & high \\
\hline & 4,00 & 0,30 & & low & medium & high & very \\
\hline & & & & & & & high \\
\hline
\end{tabular}

\subsection{Validity}

Validity testing is used to measure whether the questionnaire is valid or not, "valid" means "good" [21]. So that validity aims to measure what should be measured. The validity test in this study (see table 3 ) is known through the results of loading factors from a number of indicators showing the values of Emotional Healing, Emotional Healing, Wisdom, Persuasive Mapping, Organizational Stewardship, respectively 0.58 , $0.58,0.76$ and 0.50 .

Meanwhile, the Altruistic Calling indicator is discarded because it is invalid. The scores for the indicator affective commitment, continuance commitment and normative commitment are $0.65,0.76$, 0.65 , respectively. As for the indicators of Quality, Quantity, Timeliness, Cost effectiveness, Need for supervision, Interpersonal impact, each obtained scores of $0.63,0.66,0.69,0.54,0.70$, and 0.69 . These results indicate that from the loading factor analysis, it can be interpreted that all indicators are greater than the critical value. This means that the value measuring their latent variable is higher than the load factor of other latent variables. It can be identified that these indicators are good at measuring their latent variables [21]. Based on Table 2, it shows that the score of the square root AVE of each latent variable is actually greater than the correlation with other variables.

\subsection{Reliability}

Reliability testing in this study (see table 3), using Construct Reliability and Average Variance Extracted measurements [21]. The results show that the variables (Servant Leadership; 0.78 and 0.50), (Organizational Commitment; 0.90 and 0.50), and (Employee Performance; 0.95 and 0.50). This means that all variables have composite reliability at the Construct Reliability and Average Variance Extracted values that have met the large rule of thumb of 0.70 and 0.5 [21].

\subsection{Structural Model Analysis}

Before testing the structural model, the model in the study must be tested for its goodness of fit index first [21]. Based on the results of the model fit test shown in Figure 2, with the value of Degrees of Freedom $=296$, Minimum Fit Function Chi-Square $=839.81(\mathrm{P}=0.0)$, Normal Theory Weighted Least Squares Chi-Square = $789.99(\mathrm{P}=0.0)$ it can be concluded that the model built in this study is "The Fit is Perfect". Furthermore, structural model testing is carried out to examine the relationship between exogenous latent variables and endogenous latent variables. The results of this test can prove whether the hypothesis built on the theoretical conceptual framework is accepted or rejected. The results of hypothesis testing in this study are shown in Table 4).

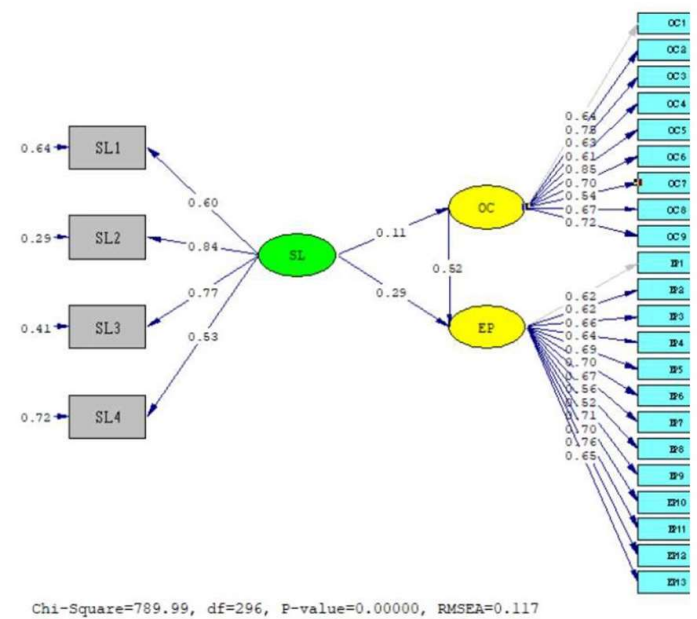

Figure 2. Hybrid Research Model 
Table 3. Validity and Reliability instrumens test result

\begin{tabular}{|c|c|c|c|c|c|c|c|c|}
\hline \multirow[t]{2}{*}{ Variable } & \multirow{2}{*}{$\begin{array}{l}\text { Laten } \\
\text { variabel }\end{array}$} & \multicolumn{3}{|c|}{ Validity } & \multicolumn{4}{|c|}{ Reliability } \\
\hline & & $\begin{array}{lll}\text { SFL }^{*} & \mathrm{C} \\
\end{array}$ & $\begin{array}{l}\text { Critical } \\
\text { Value }\end{array}$ & $\mathrm{CR}^{* *}$ & $\begin{array}{l}\text { Critical } \\
\text { Value }\end{array}$ & AVE** & $\begin{array}{l}\text { Critical } \\
\text { * Value }\end{array}$ & Hasil \\
\hline \multirow[t]{3}{*}{ Servant Leadership } & \multirow{3}{*}{$\begin{array}{l}\text { Emotional } \\
\text { Healing } \\
\text { Widom } \\
\text { Persiasip } \\
\text { Mapping } \\
\text { Org. } \\
\text { Stewardship }\end{array}$} & 0,60 & 0,5 & 0,78 & 0,7 & 0,5 & 0,5 & $\begin{array}{l}\text { Reliable } \\
\text { Valid }\end{array}$ \\
\hline & & $\begin{array}{l}0,84 \\
0,77\end{array}$ & $\begin{array}{l}0,5 \\
0,5\end{array}$ & & & & & $\begin{array}{l}\text { Valid } \\
\text { Valili }\end{array}$ \\
\hline & & 0.53 & 0,5 & & & & & Valid \\
\hline \multirow[t]{3}{*}{$\begin{array}{l}\text { Organizational } \\
\text { Commitment }\end{array}$} & \multirow{3}{*}{$\begin{array}{l}\text { Affective } \\
\text { Commit. } \\
\text { Continuance } \\
\text { Commit. } \\
\text { Normative } \\
\text { Commit. }\end{array}$} & 0,68 & 0,5 & 0,90 & 0,7 & 0,5 & 0,5 & $\begin{array}{l}\text { Reliable } \\
\text { Valid }\end{array}$ \\
\hline & & 0,72 & 0,5 & & & & & Valid \\
\hline & & 0,67 & 0,5 & & & & & Valid \\
\hline \multirow[t]{3}{*}{$\begin{array}{l}\text { Employee } \\
\text { Performance }\end{array}$} & \multirow{3}{*}{$\begin{array}{l}\text { Qyality } \\
\text { Quantity } \\
\text { Timeliness } \\
\text { Cost } \\
\text { Efectiveness } \\
\text { Need for } \\
\text { Suspension } \\
\text { Interpersonal } \\
\text { impact }\end{array}$} & $\begin{array}{l}0,62 \\
0,66 \\
0,68 \\
0,54\end{array}$ & $\begin{array}{r}0,5 \\
0,5 \\
0,5 \\
+\quad 0,5\end{array}$ & 0,98 & 0,7 & 0,5 & 0,5 & $\begin{array}{l}\text { Reliable } \\
\text { Valid } \\
\text { Valid } \\
\text { Valid } \\
\text { Valid }\end{array}$ \\
\hline & & 0,70 & 0,5 & & & & & Valid \\
\hline & & 0,70 & 00,5 & & & & & Valid \\
\hline
\end{tabular}

\subsection{Hypothesis Test}

In this study, there are 4 hypotheses (see Table 4 ). The hypothesis was tested by statistical t-test provided that Ho was rejected if the $t$-value was greater than the critical $\mathrm{t}$ value or the $\mathrm{Z}$ score was 1.64 (one tail test) for $\alpha=0.05$. Study 1 tested the direct effect on hypothesis $1,2,3$. Study 2 tests the indirect effect on hypothesis 4 . To test the significance of the indirect effect partially (Testing the mediation hypothesis), the Sobel test procedure was carried out [22]. The sobel test is done by testing the strength of the indirect effect of the independent variable $(X)$ on the dependent variable $(Z)$ through the variable (Y). The indirect effect of $\mathrm{X}$ to $\mathrm{Z}$ through $\mathrm{Y}$ is calculated by multiplying the path $\mathrm{X} \rightarrow \mathrm{Y}$ (a) by the path $\mathrm{Y} \rightarrow \mathrm{Z}$ (b) or $a b$. So the coefficient $a b=\left(c-c^{\prime}\right)$, where $c$ is the effect of $\mathrm{X}$ on $\mathrm{Z}$ without controlling $\mathrm{Y}$, while $\mathrm{c}^{\prime}$ is the coefficient of influence of $\mathrm{X}$ on $\mathrm{Z}$ after controlling for $\mathrm{Y}$. The standard error of coefficients $a$ and $b$ is written as Sa and $\mathrm{Sb}$, the magnitude of theeffect is not direct (indirect effect). Sab is calculated by the following formula:

$$
S_{a b}=\sqrt{b^{2} S_{a}^{2}+a^{2} S_{b}^{2}+S_{a}^{2} S_{b}^{2}}
$$

The results of structural model testing using SEMLisrel are shown in Table 4. The first hypothesis shows that the servant leadership (SL) variable path coefficient score on organizational commitment (OC) is 1.03 smaller than the t-critical value of 1.64 . This means that at the confidence level of $95 \%$ and $\alpha=5 \%$, Ho is accepted and $\mathrm{H} 1$ is rejected, it can be concluded that the coefficient of direct effect of SL on OC is not significant with the coefficient of determination R2 of 0.012. Thus, the first hypothesis which states that there is a positive and significant effect of servant leadership (SL) on Organizational Commitment (OC) is rejected.

The second hypothesis shows that the path coefficient score of the Organizational Commitment (OC) variable on employee performance (EP) is 3.10, which is greater than the $\mathrm{t}$-critical value of 1.64. This means that at the confidence level of $95 \%$ and $\alpha=5 \%$, Ho is rejected and $\mathrm{H} 2$ is accepted, it can be concluded that the coefficient of direct effect of SL on EP is significant with a coefficient of determination of R2 of 0.39. Thus, the second hypothesis which states that there is a positive and significant effect of servant leadership (SL) on employee performance (EP) can be accepted.

The third hypothesis shows that the path coefficient score of the organizational commitment (OC) variable on employee performance (EP) is 4.40 . is greater than the tcritical value of 1.64 . This means that at the confidence level of $95 \%$ and $\alpha=5 \%$, Ho is rejected and $\mathrm{H} 3$ is accepted, it can be concluded that the coefficient of direct influence of OC on EP is significant with the coefficient of termination R2 of 0.12 . Thus, the third hypothesis which states that there is a positive and significant influence on organizational commitment (OC) on employee performance (EP) is accepted.

The fourth hypothesis shows that the $Z$ value of the path coefficient score is calculated using the "sobel test" formula, so the effect of the servant leadership (SL) variable on employee performance (EP) through Organizational commitment (OC) is 1.65 greater than the t-critical value of 1.64. This means that at the confidence level of $95 \%$ and $\alpha=5 \%$, Ho is rejected and $\mathrm{H} 4$ is accepted, it can be concluded that the coefficient of indirect effect of SL on EP through OC is significant with the coefficient of termination R2 of 0.15 . Thus, the fourth hypothesis which states that there is a positive and significant direct influence of servant leadership (SL) on employee performance (EP) through organizational (OC) can be accepted.

Table 4. Hypothesis test result

\begin{tabular}{|c|c|c|c|c|c|c|c|}
\hline \multirow{2}{*}{ No } & \multirow{2}{*}{ Path } & \multicolumn{2}{|c|}{ Hypotheses Testing } & \multicolumn{3}{|c|}{ Coefisien of Effect $\left(R^{2}\right)$} & \multirow[t]{2}{*}{ Hypothesis } \\
\hline & & $\begin{array}{l}\text { Path } \\
\text { Coefficient }\end{array}$ & $\begin{array}{l}\text { Critical } \\
\text { Value }\end{array}$ & direct & indirect & total & \\
\hline \multicolumn{8}{|c|}{ Studi 1 (direct effect) } \\
\hline 1 & $S L \rightarrow O C$ & 1,03 & 1,64 & 0,11 & 0,00 & 0,11 & \multirow{2}{*}{$\begin{array}{l}\text { rejected } \\
\text { accepted } \\
\text { accepted }\end{array}$} \\
\hline & $\begin{array}{l}\mathrm{SL} \rightarrow \mathrm{EP} \\
\mathrm{OC} \rightarrow \mathrm{EP}\end{array}$ & $\begin{array}{l}3,10 \\
4,40 \\
\end{array}$ & $\begin{array}{l}1,64 \\
1,64 \\
\end{array}$ & $\begin{array}{l}0,29 \\
0,52 \\
\end{array}$ & $\begin{array}{l}0,00 \\
0,00 \\
\end{array}$ & $\begin{array}{l}0,29 \\
0,52 \\
\end{array}$ & \\
\hline \multicolumn{8}{|c|}{ Study 2 (mediasi effect) } \\
\hline 4 & $S L \rightarrow O C \rightarrow E P$ & & 1,64 & 0,11 & $\begin{array}{c}(0,29 * 0,52)= \\
0,15\end{array}$ & 0,26 & accepted \\
\hline \multicolumn{8}{|c|}{ Source: Data processed (2020) } \\
\hline \multicolumn{8}{|c|}{$\begin{aligned} Z \text { score } & =50 \%-5 \% \\
& =45 \% \\
& =0,45 \text { (in tabel) } \\
& =1,6+0,05=1,65 \\
Z \text { score } & =1,65>\text { critical value } 1.64, \text { lies in the area not rejected }\end{aligned}$} \\
\hline \multicolumn{8}{|c|}{ Sobel test result: } \\
\hline
\end{tabular}


Table 5. Sobel Test Result

\begin{tabular}{|c|c|c|c|c|}
\hline Input: & & Test statistic: & Std. Error: & $p$-value: \\
\hline a 0.11 & Sobel test: & 0.9743912 & 0.05870332 & 0.32986234 \\
\hline$b 0.52$ & Aroian test: & 0.95065415 & 0.0601691 & 0.34177997 \\
\hline$s_{a} 0.11$ & Goodman test: & 1 & 0.0572 & 0.31731051 \\
\hline$s_{b} 0.12$ & Reset all & & Calculate & \\
\hline
\end{tabular}

\section{DISCUSSION}

\subsection{The influence of Servant leadership on organizational commitment (H1)}

Empirically, the results of this study indicate that there is no influence between servant leadership on organizational commitment. This research contradicts the study conducted [23] who concluded that servant leadership has a strong influence on employee commitment. The study result [9] where the results of his research prove that serving leadership has a direct impact on employee performance. Conceptually it expands the understanding of servant leadership actions as a reflective construct. Leadership behavior that serves the leader and subordinates will encourage employee organizational commitment. Leaders care for employees in addition to making employees loyal to the organization; will make employees continue to strive to provide the best results from their efforts to increase organizational success [2]. However, this concept does not apply to this research, because the opinion of alumni as employees who work in companies is that the leadership generally does not provide a constructive attitude. The results showed that almost $70 \%$ of alumni as employees are absorbed in companies with medium to lower scale. From the demographics of respondents, it shows that $93 \%$ of alumni work in private companies, which could be the majority of small companies (not yet proven because of the shallowness of the research) so that the service leadership process is not implemented which can result in employees working according to what they know.

\subsection{The effect of Servant leadership on employee performance (H2)}

The results of this study support empirical testing that shows the relationship between servant leadership and employee performance by [10]. It is evident that how leaders who serve primarily with a focus on the growth and well-being of followers can influence improving individual performance in the workplace. According to the results of the correlation analysis, there is a significant level of positive correlation between the dimensions of servant leadership, the level of employee performance, further stated variables such as altruism, politeness, civil virtue, conscience, sportsmanship, and employee performance can be explained by five independent variables of servant leadership [14]. The care, assistance and ability of leaders in influencing that provided by the leadership for the work of employees can improve their performance. Employee cooperation with leaders and with other employees is also part of improving their performance also. Both alumni as employees who work in the government and private sectors able to improve their performance when leaders provide assistance in the form of influence as leaders.

\subsection{The influence of organizational commitment on employee performance (H3)}

This empirical study of the relationship of organizational commitment and employee performance is proven to support the results of the study conducted [24] that the need for strong organizational commitment is a determining factor for success in achieving higher performance. Research conducted [19] also confirmed a positive relationship between performance and commitment to effective, normative commitment. Based on the response from the statement, as the choice of place to work, alumni who act as employees in the company, make a lot of effort and care about the fate of the company, thus this is evidence of improving their performance.

\subsection{The Effect of Servant Leadership on Employee Performance is mediated by Organizational Commitment (H4)}

Empirically this study supports the influence of servant leadership on employee performance through organizational commitment, although the findings do not support service leadership and organizational commitment is not significant. Several studies have been conducted on the success of servant leadership has been achieved in non-profit companies. Setyaningrum describes the relationship between servant leadership and organizational commitment, and employee performance. The results of this study indicate that servant leadership has relevance to organizational commitment and employee performance [25]. Other than that, the findings shown that sales manager servant leadership is directly and positively related to the performance of sales staff organizational members [17]. In addition, servant leadership is indirectly related to the performance of sales members through organizational commitment felt by salespeople. 


\section{CONCLUSION}

Several previous studies have explained that servant leadership has a positive impact on organizational commitment and employee performance. Then organizational commitment has a positive impact on employee performance. This study explains and confirms the results of these studies. It was explained that there are findings that support but also refute the existing concept. In previous studies, servant leadership has a positive impact on organizational commitment but in this study it does not support this concept. However, other findings reinforce the concept of previous research, namely the existence of a positive and significant impact between organizational commitment and employee performance, a positive and significant impact between servant leadership and employee performance. With the similarities and differences in the findings of this study with previous research, it can be explained that this study was conducted specifically for secretarial almuni where all respondents were young women. Where on average they have just finished their education so that it takes time to adjust their attitudes in forming their commitments.

\section{MANAGERIAL IMPLICATIONS}

The theoretical implication of this research contributes to the management of human resources and the management literature by introducing a new model as an alternative theoretical model that can be used to gain an understanding of employee performance. Employee Performance is very dependent on organizational commitment. Employee Performance is very dependent on organizational commitment. The findings of this study can provide input for companies so that in improving the performance of their employees, leaders should not only give work orders, but can serve as servants who voluntarily want to help and pay attention to employees. On the other hand, the company should also maintain its commitment by providing full support to employees so that they really do their job.

\section{DIRECTION OF FUTURE RESEARCH}

This study was conducted on alumni who work in various types of companies, so that the diversity of companies and company scales is not the same which results in unsupportive results. It is hoped that the next research will be carried out at least in similar industries, for example the automotive industry for manufacturing companies or the banking industry for service companies.

\section{REFERENCES}

[1] N. A. Brohi, A. H. Jantan, M. A. Qureshi, R. Jaffar, J.B. Ali, J. Bin, K. Bin, \& A. Hamid, "The impact of servant leadership on employees attitudinal and behavioural outcomes attitudinal and behavioural outcomes". Cogent Business \& Management, 5(1) 2018 1-17. DOI: https://doi.org/10.1080/23311975.2018.1542652

[2] R. Setiawan, A. Eliyana, T. Suryani, \& Y. Nathan, "Increasing life satisfaction in the workplace". International Journal of Innovation, Creativity and Change, 12(12) 2020 262-274.

[3] A. Eliyana, S. Ma'arif, \& Muzakki. "Job satisfaction and organizational commitment effect in the transformational leadership towards employee performance". European Research on Management and Business Economics, 25(3) 2019 144-150. DOI: https://doi.org/10.1016/j.iedeen.2019.0 5.001

[4] R. Setiawan, A. Eliyana, T. Suryani, L.O. Osito, "World-Class Hospitality Management in Tourism Strategy: The Implementation of Servant Leadership," Journal of Talent Development and Excellence, 12(3), 2020 3122-3128.

[5] A. Eliyana, A. P. Emur, \& A. R. Sridadi, "Building Nurses' Organizational Commitment by Providing Good Quality of Work Life", Sys Rev Pharm 11(4) $2020 \quad 142-150$. https://doi.org/10.31838/srp.2020.4.22

[6] R. K. Greenleaf, Servant Leadership: A Journey into the Nature of Legitimate Power and Greatness. Indianapolis: Paulist Press, 1977

[7] R. K. Greenleaf, Servant Leadership: A Journey into the Nature of Legitimate Power and Greatness. Paulist Press, 2002

[8] N. Eva, M. Robin, S. Sendjaya, D. van Dierendonck, \& R. C. Liden, "Servant Leadership: A systematic review and call for future research", Leadership Quarterly, 30(1) 2019 111-132. DOI: https://doi.org/10.1016/j.leaqua.2018.07.004

[9] Z. R. A. Tariq, "Servent Leadership Measures and Organizational Commitment". Asian Journal of Empirical Research, 3(6) 2013 702-710.

[10] M. Chiniara, \& K. Bentein, "Linking servant leadership to individual performance: Differentiating the mediating role of autonomy, competence and relatedness need satisfaction". 
Leadership Quarterly, 27(1) 2016 124-141. DOI: https://doi.org/10.1016/j.leaqua.2015.08.004

[11] S. P. Robbins, \& T. A. Judge, Organizational Behavior (13th ed.). Pearson International Edition, Prentice -Hall, 2009

[12] F. Luthans, Organization Behavior (Eight Edit). The McGraw-Hall Co,INC, 2006

[13] B. K. Joo, S. Biyun, S. Jang, "Servant leadership, commitment, and participatory behaviors in Korean Catholic church. Journal of Management", Spirituality and Religion, 15(4) 2018 325-348. DOI: https://doi.org/https://doi.org/10.1080/14766086. 2018.1479654

[14] M. Taslyan, H. Hirlakm, "The Effect of Servent Leadership on Organizational Citizenship Behaviour and Performance of Employee: A Research on Hotel Managements in Gaziantep", ISSLETME ARAŞTIRMALARI DERGISİ JOURNAL OF BUSINESS RESEARCH-TURK, 11(1) $2019293-309 . \quad$ DOI: https://doi.org/doi.org/10.20491/isarder.2019.600

[15] S. Sendjaya, J. C. Sarros, \& J. C. Santora, "Defining and measuring servant leadership behaviour in organizations". Journal of Management Studies, 45(2) 2008 402-424. DOI: https://doi.org/10.1111/j.1467-486.2007.00761.x

[16] J. D. B. DeConinck, J. D. B. "The Relationship between Servant Leadership, Perceived Organizational Support, Performance, and Turnover among Business to Business Salespeople", Archives of Business Research, 5(10) 2017, DOI: https://doi.org/https://doi.org/10.14738/abr.510.3 730

[17] C. Otero-Neira, C. Varela-Neira, B. \& Bande. "Supervisory servant leadership and employee's work role performance: A multilevel mediation model", Leadership and Organization Development Journal, 37(7) 2016 860-881. DOI: https://doi.org/10.1108/LODJ-11-2014-0230
[18] M. S. U. Rajib, \& L. Fan, "Management Science Letters", Managment Science Letters, 10(13) 2020 3107-3118. DOI: https://doi.org/10.5267/j.msl.2020.1.004

[19] S. Suharto, \& N. Hendri, N. "The impact of organizational commitment on job performance", International Journal of Economics and Business Administration, 7(2) 2019 189-206. DOI: https://doi.org/10.35808/ijeba/227

[20] E. Chinomona, \& T. Mofokeng, "Impact of leadership on organizational citizenship behaviour, organizational commitment and job performance: An application of leader- member exchange theory". Corporate Ownership and Control, 14(3) 2017 309-319. DOI: https://doi.org/10.22495/cocv14i3c2art5

[21] E. K. Riadi Edi, Statistik SEM: structural equation modeling dengan LISREL. Yogyakarta: Penerbit Andi, 2018

[22] R. B. Kline, Principles and practice of structural equation modelling ( $4^{\text {th }}$ ed.). Methodology in the Social Sciences, 2015

[23] F. Cesário, \& M. J. Chambel, (2017). "Linking Organizational Commitment and Work Engagement to Employee Performance". Knowledge and Process Management, 24(2) 2017 152-158. DOI: https://doi.org/10.1002/kpm.1542

[24] T. M. E. Chinomona "Impact of Leadership on Organizational Citizenship Behaviour, Organizational Commitment and Job Performance: an Application of Leadermember Exchange Theory". Journal Corporate Ownership \& Control, 14(3) 2017. DOI: https://doi.org/10.22495/cocv14i3c2art5

[25] R.P. Setyaningrum, M. Setiawan, \& S. Surachman, "Organizational Commitments Are Mediation of Relationships Between Servant Leadership and Employee Performance". Jurnal Aplikasi Manajemen, 15(4) 2017 693-701. DOI: https://doi.org/10.21776/ub.jam2017.015.04.17 